\title{
Is Pethidine Safe during Labor? Systematic Review
}

\section{A petidina é segura durante o trabalho de parto? Revisão sistemática}

\author{
Rogevando Rodrigues Nunes ${ }^{1}$ Paulo Giordano Baima Colares ${ }^{2}$ Juliana Pinto Montenegro 3 \\ ${ }^{1}$ Obstetrician, Postgraduate vice-rectory, Health Science Center, MSc \\ in Medical Sciences, Universidade de Fortaleza (UNIFOR), Fortaleza, \\ CE, Brazil \\ 2 Orthopedist/Traumatology, Universidade de Fortaleza (UNIFOR), \\ Fortaleza, CE, Brazil \\ 3 Physiotherapist, Universidade de Fortaleza (UNIFOR), Fortaleza, \\ CE, Brazil \\ Rev Bras Ginecol Obstet 2017;39:686-691.

\begin{abstract}
Address for correspondence Rogevando Rodrigues Nunes, Obstretrician, MSc, Universidade de Fortaleza, Fortaleza, CE, 60811-905, Brazil (e-mail: rogevando@hotmail.com).
\end{abstract}

\begin{abstract}
Purpose To verify if pethidine is safe for the conceptus when used during labor. Methods Systematic review in the Capes Periodicals/PubMed and MEDLINE/Virtual Health Library (BVS, in the Portuguese acronym) databases.

Results A total of 17 studies published from January 1st, 2000, to September 2nd,

Keywords

- pethidine

- safety

- labor

\section{Resumo}

\section{Palavras-chave}

- petidina

- segurança

- trabalho de parto 2016 , with a total of 1,688 participants involved were included in the present review. There was no record of conceptus vitality decrease associated with low doses of pethidine being administered to mothers during labor.

Conclusions Intramuscular (IM) or intravenous (IV) pethidine at low doses, of up to $50 \mathrm{mg}$, is safe to administer during labor.

Objetivo Verificar se a petidina é segura para o concepto quando utilizada durante o trabalho de parto.

Método Revisão sistemática nas bases de dados dos Periódicos Capes/PubMed e MEDLINE/Biblioteca Virtual em Saúde (BVS).

Resultados Um total de 17 estudos, publicados de $1^{\circ}$ de janeiro de 2000 a 2 de setembro de 2016, totalizando 1.688 participantes envolvidos, foram incluídos nesta revisão. Não houve registro de depressão na vitalidade dos conceptos com doses baixas de petidina administradas às mães durante o trabalho de parto.

Conclusão Petidina intramuscular (IM) ou intravenosa (IV) em baixas doses, de até $50 \mathrm{mg}$, é segura durante o trabalho de parto.
\end{abstract}

\section{Introduction}

Strictly speaking, all drugs cause changes of different magnitudes and with variable duration in the maternal and/or

received

February 23, 2017

accepted

April 19, 2017

published online

June 30, 2017 10.1055/s-0037-1604065 ISSN $0100-7203$. fetal organism. In order for a drug to be considered safe to be used during labor, it must be unable to cause deleterious changes that could result in any sequel to the mother or her conceptus.
Copyright $\odot 2017$ by Thieme Revinter

Publicações Ltda, Rio de Janeiro, Brazil
License terms

(요 (1) $\Theta \circledast$ 
Labor pain is described as strong in 40 to $70 \%$ of cases. ${ }^{1,2}$ Intense suffering is usual in many parturients. Science has been trying to solve this problem for centuries; however, progress has been slow in achieving this goal. Since the 19th Century, medicine has used systemic analgesics during labor $^{3}$, but, even after nearly 200 years, medicine has not found any potent, safe, easy to use and affordable drug to be administered during this period.

The side effects of the drugs used during pregnancy have always been a medical concern. A drug that is safe for the mother can be harmful to the conceptus because of its immaturity. Therefore, the use of any drug should take into account maternal and fetal safety. ${ }^{4}$

For the past 50 years, the gold standard in labor analgesia has been continuous epidural anesthesia. ${ }^{5}$ When it is not available, contraindicated or refused, opioids are the best option. ${ }^{6}$ Pethidine is an opioid derivative first synthesized in 1939 in Germany. ${ }^{7}$ Like any drug, it has its potency and its side effects related to the administered dose. During labor, pethidine may be administered intravenously (IV, at doses between $25-50 \mathrm{mg}$ ) or intramuscularly (IM, at doses between $50-100 \mathrm{mg}){ }^{8}$ It has been used for 76 years in labor analgesia, with various dosages and routes of administration. ${ }^{9}$ It is a low-cost and easy to handle analgesic. ${ }^{10}$ However, its use has been widely questioned because of the possible side effects on the conceptus, mainly respiratory depression. ${ }^{11,12}$ Traditionally, asphyxia and respiratory depression in newborns are measured by means of clinical and laboratorial analyses of the Apgar score, the $\mathrm{pH}$ and the blood gases (hypoxemia and hypercapnia). ${ }^{13}$ This drug has not been correlated with significant negative impacts on the maternal organism when administered in moderate doses during labor. ${ }^{14}$

After analyzing conflicting studies about the safety of pethidine for the conceptus, many services are decreasing or abolishing its use during labor.

This systematic review aims to compare the results of 17 studies involving pethidine use during labor. The purpose is to verify if pethidine is safe for the conceptus.

\section{Methods}

This systematic review was conducted through a search for publications indexed in the Capes Periodicals/PubMed and MEDLINE/Virtual Health Library (BVS, in the Portuguese acronym) databases and published from January 1st, 2000, to September 2nd, 2016. The following keywords were used alone or combined with each other: pethidine in labor. A total of 243 articles were found. The exclusion criteria were: a) repeated articles; b) systematic review articles; c) lack of evaluation of conceptus vitality; d) studies using pethidine associated with promethazine; e) sample size below 25 patients; f) articles whose participants were not given pethidine IV or IM; g) non-randomized articles, h) meta-analysis articles; and i) articles of very restricted access.

Systematic reviews and meta-analyses were excluded to avoid duplication in the data analysis; articles with less than
25 patients were not included because they are more prone to erroneous conclusions; non-randomized studies were left out of the review because they have less reliable results, and studies in which promethazine was administered were excluded because promethazine can cause respiratory depression in the newborn. ${ }^{15}$

After exclusion of 68 duplicated articles, 175 were selected; of these, 11 were excluded because they were systematic reviews; 3 articles did not assess the conceptus vitality; 4 were excluded because they used promethazine; 3 studies were excluded because they had less than 25 participants; 123 articles were excluded for not using pethidine IV or IM in labor analgesia; 6 articles were non-randomized, and 8 were excluded for being of very restricted access. Finally, 17 articles were analyzed for the present review, being 10 free-access articles and 7 restricted-access articles (-Fig. 1 ).

243 articles in the Capes/PubMed and MEDLINE/BVS databases from 2000 to 2016
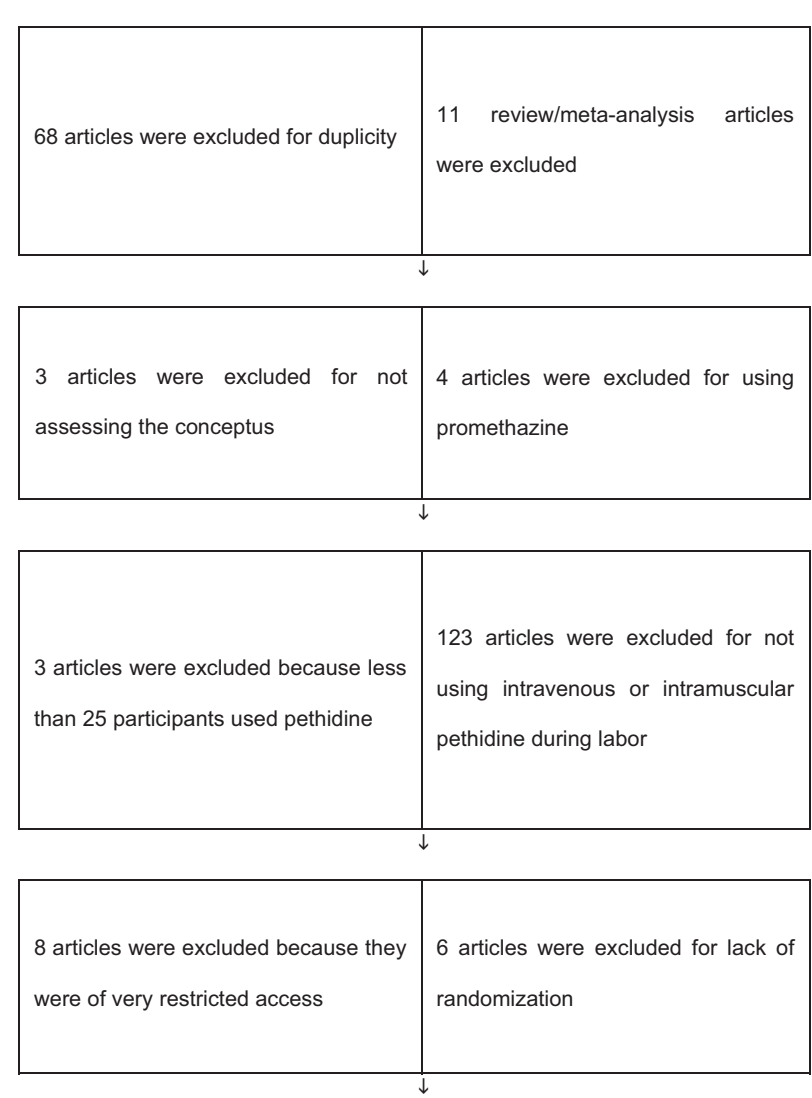

17 articles were included in the systematic review (10 free-access and 7

restricted-access articles)

Fig. 1 Flow chart of the excluded and selected articles. 
Table 1 Analyzed articles

\begin{tabular}{|c|c|c|c|c|}
\hline Author, publishing date & $\begin{array}{l}\text { Type of } \\
\text { study/country }\end{array}$ & $\mathrm{N}$ & $\begin{array}{l}\text { Dose/route of } \\
\text { administration }\end{array}$ & Neonatal outcomes \\
\hline $\begin{array}{l}\text { El-Refaie et al }{ }^{16} \\
2012\end{array}$ & $\begin{array}{l}\text { RCT/ } \\
\text { Egypt }\end{array}$ & 120 & $50 \mathrm{mg} / \mathrm{IV}$ & $\begin{array}{l}\text { Pethidine x placebo. There were no differences } \\
\text { in Apgar scores }(7.4 \times 7.7) \text {, respiratory } \\
\text { depression, } \mathrm{pH} \text {, and arterial blood gases of } \\
\text { the NBs. }\end{array}$ \\
\hline $\begin{array}{l}\text { Khooshideh and Shahriari }{ }^{17} \\
2009\end{array}$ & RCT/Iran & 80 & $50 \mathrm{mg} / \mathrm{IM}$ & $\begin{array}{l}\text { Pethidine } x \text { tramadol. All Apgar scores at } 1 \\
\text { and } 5 \text { minutes were }>7 \text {. There were } 3 \text { cases } \\
\text { of fetal distress ( } 2 \text { participants had been } \\
\text { given pethidine). }\end{array}$ \\
\hline $\begin{array}{l}\text { Allameh et al }{ }^{18} \\
2015\end{array}$ & $\begin{array}{l}\mathrm{RCT} / \\
\text { Iran }\end{array}$ & 30 & $50 \mathrm{mg} / \mathrm{IM}$ & $\begin{array}{l}\text { Pethidine } x \text { acupuncture } x \text { placebo. The } \\
\text { Apgar scores were } 8 / 9 \text { in the } 3 \text { groups. There } \\
\text { were no differences in the number of NBs } \\
\text { who passed meconium. }\end{array}$ \\
\hline $\begin{array}{l}\text { Yilmaz et al } \\
2009\end{array}$ & $\begin{array}{l}\text { RCT/ } \\
\text { Turkey }\end{array}$ & 48 & $50 \mathrm{mg} / \mathrm{IV}$ & $\begin{array}{l}\text { Pethidine } x \text { valethamate } x \text { placebo. There } \\
\text { were no differences in the number of NBs } \\
\text { who passed meconium or the number of } \\
\text { Apgar scores at } 1 \text { or } 5 \text { minutes }<7 \text {. }\end{array}$ \\
\hline $\begin{array}{l}\text { Sekhavat and Behdad }{ }^{20} \\
2009\end{array}$ & $\begin{array}{l}\mathrm{RCT} / \\
\text { Iran }\end{array}$ & 75 & $50-75 \mathrm{mg} / \mathrm{IM}$ & $\begin{array}{l}\text { Pethidine } x \text { placebo. There was a decrease in } \\
\text { the variability of the fetal heart rate. There } \\
\text { were no significant adverse effects on the } \\
\text { NBs. }\end{array}$ \\
\hline $\begin{array}{l}\mathrm{Ng} \text { et } \mathrm{al}^{21} \\
2011\end{array}$ & $\begin{array}{l}\text { RCT/ } \\
\text { China }\end{array}$ & 34 & $50-75 \mathrm{mg} / \mathrm{IM}$ & $\begin{array}{l}\text { Pethidine } x \text { remifentanil. The Apgar scores } \\
\text { were } 8 / 9 \text {. No complications were reported. }\end{array}$ \\
\hline $\begin{array}{l}\text { Elbohoty et al } 22 \\
2012\end{array}$ & $\begin{array}{l}\text { RCT/ } \\
\text { Egypt }\end{array}$ & 50 & $50 \mathrm{mg} / \mathrm{IV}$ & $\begin{array}{l}\text { Pethidine x paracetamol. The Apgar scores at } \\
1 \text { minute were lower in the group using } \\
\text { pethidine }(6 \times 7) \text {. All Apgar scores at } 5 \\
\text { minutes were } 9 \text {. No adverse effects or } \\
\text { admissions to the intensive care unit were } \\
\text { reported. }\end{array}$ \\
\hline $\begin{array}{l}\text { Fleet et } a l^{23} \\
2015\end{array}$ & $\begin{array}{l}\text { RCT/ } \\
\text { Australia }\end{array}$ & 51 & $\begin{array}{l}100 \mathrm{mg} / \mathrm{IM}, \\
\text { every } 3 \text { hours }\end{array}$ & $\begin{array}{l}\text { Pethidine } x \text { fentanyl. Apgar score at } 1 \text { and } 5 \\
\text { minutes was } 9 \text { for both groups. There was a } \\
\text { higher number of NBs admissions to the } \\
\text { nursery with pethidine. }\end{array}$ \\
\hline $\begin{array}{l}\text { Loughnan et } \mathrm{al}^{24} \\
2000\end{array}$ & $\begin{array}{l}\text { RCT/ } \\
\text { England }\end{array}$ & 213 & $\begin{array}{l}100 \mathrm{mg} / \mathrm{IM} \text {, } \\
\text { every } 2 \text { hours }\end{array}$ & $\begin{array}{l}\text { Pethidine } x \text { epidural. No differences in the } \\
\text { number of Apgar scores }<9 \text { at } 5 \text { minutes. }\end{array}$ \\
\hline $\begin{array}{l}\text { Keskin et } \mathrm{al}^{25} \\
2003\end{array}$ & $\begin{array}{l}\text { RCT/ } \\
\text { Turkey }\end{array}$ & 29 & $100 \mathrm{mg} / \mathrm{IM}$ & $\begin{array}{l}\text { Pethidine } x \text { tramadol. The Apgar scores of } \\
\text { both groups were }>7 / 9 \text {. There were no } \\
\text { differences in Apgar scores number of the } \\
\text { respiratory depression. There were } 3 \text { cases of } \\
\text { respiratory depression in the NBs of the } \\
\text { participants who were given pethidine } \\
(10.3 \%) \text {. }\end{array}$ \\
\hline $\begin{array}{l}\text { Wee et al } 26 \\
2014\end{array}$ & $\begin{array}{l}\text { RCT/ } \\
\text { England }\end{array}$ & 240 & $150 \mathrm{mg} / \mathrm{IM}$ & $\begin{array}{l}\text { Pethidine } x \text { diamorphine. The Apgar at } 1 \\
\text { minute was }<7 \text { in } 15 \% \text { of the participants } \\
\text { who were given pethidine, and there was } \\
\text { need for resuscitation in } 19 \% \text { of the } \\
\text { participants. }\end{array}$ \\
\hline $\begin{array}{l}\text { Sosa et } a l^{27} \\
2004\end{array}$ & $\begin{array}{l}\text { RCT/ } \\
\text { Uruguay }\end{array}$ & 205 & $100 \mathrm{mg} / \mathrm{IV}$ & $\begin{array}{l}\text { Pethidine } x \text { placebo. There was respiratory } \\
\text { depression and acidosis in the NBs whose } \\
\text { mothers were given pethidine. }\end{array}$ \\
\hline $\begin{array}{l}\text { Sharma et } \mathrm{al}^{28} \\
2002\end{array}$ & $\begin{array}{l}\mathrm{RCT} / \\
\text { United States }\end{array}$ & 207 & $\begin{array}{l}50 \mathrm{mg} / \mathrm{IV}+15 \mathrm{mg} / \mathrm{IV} \text {, } \\
\text { every } 10 \text { minute, } \\
\text { limited to } 100 \mathrm{mg} \\
\text { every } 2 \text { hours }\end{array}$ & $\begin{array}{l}\text { Pethidine } x \text { epidural. There were no } \\
\text { differences in arterial blood } \mathrm{pH} \text { between the } \\
\text { two groups. In the group that was given } \\
\text { pethidine, Apgar scores }<7 \text { at } 1 \text { minute } \\
\text { were more frequent. }\end{array}$ \\
\hline $\begin{array}{l}\text { Sosa et } \mathrm{al}^{29} \\
2006\end{array}$ & $\begin{array}{l}\text { RCT/ } \\
\text { Uruguay }\end{array}$ & 189 & $100 \mathrm{mg} / \mathrm{IV}$ & $\begin{array}{l}\text { Pethidine } x \text { placebo. There was no associa- } \\
\text { tion between pethidine and acidosis in the } \\
\text { NBs. }\end{array}$ \\
\hline
\end{tabular}


Table 1 (Continuation)

\begin{tabular}{|c|c|c|c|c|}
\hline Author, publishing date & $\begin{array}{l}\text { Type of } \\
\text { study/country }\end{array}$ & $\mathrm{N}$ & $\begin{array}{l}\text { Dose/route of } \\
\text { administration }\end{array}$ & Neonatal outcomes \\
\hline $\begin{array}{l}\text { Tsui et } \mathrm{al}^{30} \\
2004\end{array}$ & $\begin{array}{l}\text { RCT/ } \\
\text { China }\end{array}$ & 25 & $100 \mathrm{mg} / \mathrm{IM}$ & $\begin{array}{l}\text { Pethidine } x \text { placebo. There were no } \\
\text { differences in the } \mathrm{pH} \text { of the umbilical vein. } \\
\text { The number of Apgar scores }<7 \text { at } 1 \text { and } \\
5 \text { minutes was equal. }\end{array}$ \\
\hline $\begin{array}{l}\text { Douma et } \mathrm{al}^{31} \\
2010\end{array}$ & $\begin{array}{l}\text { RCT/ } \\
\text { Netherlands }\end{array}$ & 53 & $\begin{array}{l}49,5 \mathrm{mg} / \mathrm{IV}+5 \mathrm{mg} / \mathrm{IV} \text {, } \\
\text { every } 5 \text { minutes }\end{array}$ & $\begin{array}{l}\text { Pethidine } x \text { fentanyl } x \text { remifentanil. The } \\
\text { Apgar scores with pethidine were } 8.6 / 9.7 \text {. } \\
\text { Those using pethidine had umbilical cord IV, } \\
\text { blood with pH } 5 / 5 \text { minute } 7.21 \text { (0.1)-limitary } \\
\text { and NACS } 36.8(2.1) \text {-limitary. }\end{array}$ \\
\hline $\begin{array}{l}\text { Jain et } \mathrm{al}^{32} \\
2003\end{array}$ & $\begin{array}{l}\mathrm{RCT} / \\
\text { India }\end{array}$ & 39 & $50-75-100 \mathrm{mg} / \mathrm{IM}$ & $\begin{array}{l}\text { Pethidine } x \text { epidural } x \text { tramadol. There were } \\
\text { no differences in the Apgar scores at } 1 \text { and } \\
5 \text { minutes among the three groups. Umbilical } \\
\text { cord } \mathrm{pH} \text { was similar in all groups. }\end{array}$ \\
\hline
\end{tabular}

Abbreviations: IM, intramuscular; IV, intravenous; N, size of the sample who was given pethidine; NACS, neurological and adaptive capacity score (normal: > 35); NBs, newborns; RCT, randomized clinical trial.

Note: Normal pH of the umbilical vein: between 7.20 and 7.45.

\section{Results}

The 17 remaining articles, which included a total of 1,688 participants to whom pethidine was administered during labor, were analyzed (-Table 1). The publications were from countries located in Europe, Asia, South America, North America, Oceania and Africa. They were grouped in order according to the drug dosages administered (from the lowest to the highest dosages) to facilitate the analysis. There was a wide variation in the number of participants in each study, from 25 to 240. Seven articles compared pethidine with placebo (totaling 692 participants), and 10 articles compared pethidine with another analgesic drug (totaling 996 participants). Even when compared with other drugs, it was possible to analyze the safety of pethidine for the conceptus when it was administered during labor.

\section{Discussion}

More than $70 \%$ of the 17 studies were concentrated in Asia, Africa and Latin America (Iran: 03; Turkey: 02; Egypt: 02; China: 02; India: 01; and Uruguay: 02). Most studies involving pethidine in labor analgesia are conducted in the developed countries of North America or Europe. Emerging countries are more concerned in seeking options for labor analgesia.

A total of 10 articles were published in the past 7 years. The 7 articles in which pethidine was administered at a dose of $50 \mathrm{mg}$ were published in the past 7 years. The articles show that currently there is a tendency to use lower doses of pethidine.

Several articles provided incomplete data for an optimal analysis. Some articles did not publish the Apgar scores; others articles did not report how many newborns required cardiopulmonary resuscitation, admission to the nursery or intensive care unit (ICU). An ideal evaluation of newborn vitality should include at the same time: the Apgar score; the need for ventilator assistance; and an analysis of the umbilical vein blood, to determine the $\mathrm{pH}$ and the blood gases. The analysis of some of these parameters alone or partially combined may not show the correct answer to the harm caused by the use of certain medications.

During the evaluation of neonatal outcomes, the following clinical and/or laboratory criteria were used: presence of respiratory depression; need for resuscitation; Apgar score; $\mathrm{pH}$; hypoxemia; and hypercapnia. Only one study used the neurological and adaptive capacity score (NACS), which is inaccurate and unreliable. ${ }^{33}$

More than one variable was used in $88 \%$ of the articles to analyze the safety of pethidine, and $82 \%$ of them used the Apgar score to assess the newborns. Although the Apgar score may have a minor subjective aspect, it is easy to use, and is widely adopted in the evaluation of newborns.

The Apgar score was devised in 1952 by Virginia Apgar, an American anesthesiologist. It consists of 5 parameters, which can receive scores from 0 to 2: pulse rate; respiratory effort; activity; reflex reaction; and skin color. - Table 2 shows the parameters of the Apgar score. It is the most widely used assessment of neonatal vitality, as it is quick and easy to perform. The 1-minute Apgar score is related to birth conditions, and the 5-minute Apgar score regards the prognosis of the newborn. Ideally, both the 1-minute and 5-minute Apgar score must be $>7 .^{34}$

A study in Egypt, in which $50 \mathrm{mg}$ of IV pethidine was administered to 120 pregnant women in labor, showed that there were no changes in the vitality of the newborns compared with placebo. The Apgar scores were similar, and all above 7; the $\mathrm{pH}$ and the arterial blood gases of the newborns were equal, and there was no record of respiratory depression. The results of this study lead us to conclude that 
Table 2 Apgar score

\begin{tabular}{|l|l|l|l|}
\hline Vital sign & $\mathbf{0}$ & $\mathbf{1}$ & $\mathbf{2}$ \\
\hline Pulse rate & Absent & Low (below 100) & More than 100 \\
\hline Respiratory effort & Absent & Slow, irregular & Good, crying \\
\hline Muscle tone & Flaccid & The presence of any bending of the ends & Active movements \\
\hline Reflex reaction & No reaction & Grimace & Vigorous cry \\
\hline Color & Blue, pale & Body pink, blue ends & Completely rosy \\
\hline
\end{tabular}

Source: Adapted from Apgar. ${ }^{34}$

pethidine is safe at this dose and with the route of administration used.

In 6 studies in which pethidine was administered at a dose of $50 \mathrm{mg}$ IV or IM, there were no significant adverse effects on the newborns, and no Apgar scores $<7$ were found. ${ }^{16-21}$ Only in a survey using $50 \mathrm{mg}$ of IV pethidine, the Apgar score at 1 minute was $6,{ }^{22}$ but without complications for the newborn or admissions to the ICU. These findings demonstrate that pethidine, IM or IV, is safe during labor at this dose.

In studies that used more than $50 \mathrm{mg}$ of pethidine, IM or IV, there was inconsistency in the results: 3 of them (totaling 117 participants) concluded it was safe; ${ }^{30-32}$ and 7 studies (totaling 1,134 participants) found correlations with alterations in the newborn, especially respiratory depression, low Apgar scores, or need for resuscitation. ${ }^{23-29}$

The number of participants who were given $50 \mathrm{mg}$ of pethidine was 437 , representing $\sim 26 \%$ of the total; this reflects the preference for researches employing more than $50 \mathrm{mg}$ of pethidine, especially before 2006. Ideally, we need a study comparing pethidine at 2 doses: $50 \mathrm{mg}$ and $>50 \mathrm{mg}$, with the same number of participants in each group.

Depending on the habits of the population, such as the frequent use of certain drugs, the metabolism of pethidine can be faster among the inhabitants of some countries. As these were multicenter studies, there may be a variation in the side effects of pethidine associated with the observed pharmacological culture in the region.

As a rule, the risk of a drug depends on the route of administration and dose used. There is no harmless drug. The risk/benefit ratio should always be taken into account before administering pethidine.

Some studies used placebo and found lower Apgar scores than others that used pethidine. ${ }^{16,31}$ This is due to the subjectivity in determining the Apgar scores in the different studies, which leads to some difficulty in comparing them.

Drugs such as pethidine should have a table listing increasing doses with the appearance of side effects. Thus, it would be easier to use these drugs, always taking into account their risks and benefits.

\section{Conclusions}

The administration during labor of IM or IV pethidine at low doses, of up to $50 \mathrm{mg}$, is safe for the conceptus. Doses above $>50 \mathrm{mg}$ should be avoided, since they require further studies to obtain definitive evidence.

\section{Note}

This study was conducted in partnership with Universidade de of Fortaleza (UNIFOR), through the access granted to the digital library of the institution. The authors are part of the MSc Academic Course in Medical Sciences at UNIFOR.

\section{References}

1 Ronconi APL, Perdichizzi FS, Pires OC, Constantino E, Lopes VR, Posso IP. Dor e satisfação durante o trabalho de parto em primigestas: visão da parturiente e do obstetra. Rev Dor. 2010;11(04):277-281

2 Nilsen E, Sabatino H, Lopes MHBM. The pain and behavior of women during labor and the different positions for childbirth. Rev Esc Enferm USP 2011;45(03):557-565

3 Chestnut DH, Wong CA, Tsen LC, Kee WDN, Beilin Y, Mhyre J. Anestesia obstétrica: princípios e prática. 5a ed. Rio de Janeiro: Elsevier; 2016

4 Koren G. Medication safety in pregnancy \& breastfeeding. New York: McGraw-Hill; 2007

5 Kandel PF, Spoerel WE, Kinch RAH. Continuous epidural analgesia for labour and delivery: review of 1000 cases. Can Med Assoc J 1966;95(19):947-953

6 Shahriari A, Khooshideh M. A randomized controlled trial of intravenous remifentanil compared with intramuscular meperidine for pain relief in labor. J Med Sci 2007;7(04):635-639

7 Barnes J. Pethidine in labour; results in 500 cases. BMJ 1947; 1(4500):437-442

8 Bismarck JA. Analgesia em obstetrícia. Lisboa: Permanyer Portugal; 2002

9 Abu Dayyh W, El Tannir D, Mallah E, et al. Pethidine level in Jordanian women and their newborns during labor after a single intravenous dose. Int J Clin Anesthesiol. 2014;2(03):1-7

10 Freitas JF, Meinberg S. Analgesia de parto: bloqueios locorregionais e analgesia sistêmica. Rev Med Minas Gerais. 2009;19(03, Suppl 1):S7-S14

11 Reynolds F. Labour analgesia and the baby: good news is no news. Int J Obstet Anesth 2011;20(01):38-50

12 Minson FP, Ferracini FT, Fernandes Júnior CJ, Sardá Júnior J, Lopes ACB. Redução do uso de Petidina em hospital privado com a implantação de um programa educativo multiprofissional. Rev Dor. 2011;12(01):35-38

13 Dastur AE. Intrapartum fetal distress. J Obstet Gynaecol India 2005;55(02):115-117

14 Yaksh TL, Wallace MS. Opioids, analgesia, and pain management. In: Brunton LL, Chabner BA, Knollmann BC, editors. Goodman and 
Gilman's the pharmacological basis of therapeutics. 12th ed. New York: McGraw-Hill; 2011. p. 481-526

15 Briggs GG, Freeman RK, Yaffe SJ. Drugs in pregnancy and lactation: a reference guide to fetal and neonatal risk. $9^{\text {th }}$ ed. Philadelphia: Lippincott Williams \& Wilkins; 2011. Promethazine; p. 1219-20

16 El-Refaie TA, El-Said MM, Shoukry AA, Khafagy SM, El-Din AS, Badawy MM. Meperidine for uterine dystocia and its effect on duration of labor and neonatal acid-base status: a randomized clinical trial. J Obstet Gynaecol Res 2012;38(02):383-389

17 Khooshideh M, Shahriari A. A comparison of tramadol and pethidine analgesia on the duration of labour: a randomised clinical trial. Aust N Z J Obstet Gynaecol 2009;49(01):59-63

18 Allameh Z, Tehrani HG, Ghasemi M. Comparing the impact of acupuncture and pethidine on reducing labor pain. Adv Biomed Res 2015;4:46

19 Yilmaz B, Kart C, Kelekci S, et al. Meperidine versus valethamate bromide in shortening the duration of active labor. Int J Gynaecol Obstet 2009;107(02):126-129

20 Sekhavat L, Behdad S. The effects of meperidine analgesia during labor on fetal heart rate. Int J Biomed Sci 2009;5(01):59-62

21 Ng TKT, Cheng BCP, Chan WS, Lam KK, Chan MTV. A double-blind randomised comparison of intravenous patient-controlled remifentanil with intramuscular pethidine for labour analgesia. Anaesthesia 2011;66(09):796-801

22 Elbohoty AEH, Abd-Elrazek H, Abd-El-Gawad M, Salama F, ElShorbagy M, Abd-El-Maeboud KHI. Intravenous infusion of paracetamol versus intravenous pethidine as an intrapartum analgesic in the first stage of labor. Int J Gynaecol Obstet 2012;118(01): 7-10

23 Fleet J, Belan I, Jones MJ, Ullah S, Cyna AM. A comparison of fentanyl with pethidine for pain relief during childbirth: a randomised controlled trial. BJOG 2015;122(07):983-992

24 Loughnan BA, Carli F, Romney M, Doré CJ, Gordon H. Randomized controlled comparison of epidural bupivacaine versus pethidine for analgesia in labour. Br J Anaesth 2000;84(06):715-719
25 Keskin HL, Keskin EA, Avsar AF, Tabuk M, Caglar GS. Pethidine versus tramadol for pain relief during labor. Int J Gynaecol Obstet 2003;82(01):11-16

26 Wee MYK, Tuckey JP, Thomas PW, Burnard S. A comparison of intramuscular diamorphine and intramuscular pethidine for labour analgesia: a two-centre randomised blinded controlled trial. BJOG 2014;121(04):447-456

27 Sosa CG, Balaguer E, Alonso JG, Panizza R, Laborde A, Berrondo C. Meperidine for dystocia during the first stage of labor: A randomized controlled trial. Am J Obstet Gynecol 2004;191(04): $1212-1218$

28 Sharma SK, Alexander JM, Messick G, et al. Cesarean delivery: a randomized trial of epidural analgesia versus intravenous meperidine analgesia during labor in nulliparous women. Anesthesiology 2002;96(03):546-551

29 Sosa CG, Buekens P, Hughes JM, et al. Effect of pethidine administered during the first stage of labor on the acid-base status at birth. Eur J Obstet Gynecol Reprod Biol 2006;129(02):135-139

30 Tsui MHY, Ngan Kee WD, Ng FF, Lau TK. A double blinded randomised placebo-controlled study of intramuscular pethidine for pain relief in the first stage of labour. BJOG 2004;111(07): 648-655

31 Douma MR, Verwey RA, Kam-Endtz CE, van der Linden PD, Stienstra R. Obstetric analgesia: a comparison of patient-controlled meperidine, remifentanil, and fentanyl in labour. Br J Anaesth 2010;104(02):209-215

32 Jain S, Arya VK, Gopalan S, Jain V. Analgesic efficacy of intramuscular opioids versus epidural analgesia in labor. Int J Gynaecol Obstet 2003;83(01):19-27

33 Halpern SH, Littleford JA, Brockhurst NJ, Youngs PJ, Malik N, Owen $\mathrm{HC}$. The neurologic and adaptive capacity score is not a reliable method of newborn evaluation. Anesthesiology 2001;94(06): 958-962

34 Apgar V. A proposal for a new method of evaluation of the newborn infant. Curr Res Anest Anal 1953;32(04):260-267 